\title{
Association between transforming growth factor $\beta 1$ polymorphisms and atrial fibrillation in essential hypertensive subjects
}

\author{
Yongzheng Wang ${ }^{1}$, Xuwei Hou${ }^{2}$, Yuliang $\mathrm{Li}^{{ }^{*}}$
}

\begin{abstract}
Background: The association of TGF $\beta 1$ polymorphisms and atrial fibrillation (AF) in essential hypertensive (EH) subjects remains unknown. Methods $\mathrm{EH}$ subjects with $\mathrm{AF}(\mathrm{EH}+\mathrm{AF}+)$ and sinus rhythm $(\mathrm{EH}+\mathrm{AF}-)$ were enrolled. The polymorphisms of $+869 \mathrm{~T} \rightarrow \mathrm{C}$ at codon 10 and $+915 \mathrm{G} \rightarrow \mathrm{C}$ at codon 25 , were genotyped. The clinical characteristics including serum TGF $\beta 1$ levels were detected.

Results: The GG genotypes of TGF $\beta 1+915 \mathrm{G} \rightarrow \mathrm{C}$ at codon 25 were more prevalent in subjects from $\mathrm{EH}+\mathrm{AF}+$ group than those from EH+AF- group $(P=0.009)$. The subjects with $G G$ genotype from $E H+A F+$ group had the highest mean serum TGF $\beta 1$ level, which was significantly higher than that of GG genotype subjects from EH+AFgroup ( $3.18 \pm 0.24 \mathrm{ng} / \mathrm{dl}$ vs.2.29 $\pm 0.14 \mathrm{ng} / \mathrm{dl}, \mathrm{P}<0.05)$. Multiple analyses revealed that the TGF $\beta 1 \mathrm{GG}$ genotype of $+915 \mathrm{G} \rightarrow \mathrm{C}$ at codon 25 presented a 3.09 times higher risk in developing AF in the multivariate model after adjusting for age and gender.

Conclusion: The polymorphisms of TGF $\beta 1+915 \mathrm{G} \rightarrow \mathrm{C}$ at codon 25 were associated with occurrence of AF and serum TGF $\beta 1$ level in EH subjects.
\end{abstract}

\section{Background}

Atrial fibrillation (AF) is a common and clinically important arrhythmia in practice, which represents a major public health problem. AF induces hemodynamic impairment and thromboembolic events, resulting in significant morbidity, mortality, and cost [1,2].

A number of factors, e.g. age, coronary artery disease, myocardial infarction, heart failure, valvular heart disease, contribute to the occurrence and development of AF $[3,4]$. In addition, population based studies revealed that hypertension is an independent risk factor for onset of AF [5]. The risk of developing AF in hypertensives was 1.9 times higher than normtensives in the Framingham Heart Study [6].

The precise mechanism of AF remains largely unknown. Compelling evidence showed that the atrial fibrosis is essential for the onset and maintenance of AF [7]. Atrial fibrosis causes conduction abnormalities which results in an increase in AF vulnerability.

\footnotetext{
* Correspondence: liyuliang120@yahoo.cn
'Department of Interventional Radiology, The Second Hospital of Shandong

* Correspondence: liyuliang120@yahoo.cn
'Department of Interventional Radiology, The Second Hospital of Shandong University, Shangdong, PR China
}

(c) 2010 Wang et al; licensee BioMed Central Ltd. This is an Open Access article distributed under the terms of the Creative Commons Attribution License (http://creativecommons.org/licenses/by/2.0), which permits unrestricted use, distribution, and reproduction in any medium, provided the original work is properly cited.

Increased atrial fibrosis was observed in the biopsy and autopsy specimens from patients with AF [7-15].

Transforming growth factor $\beta 1$, (TGF $\beta 1$ ) is a cytokine that modulates the tissue fibrosis. Previous study showed that over-expression of TGF $\beta 1$ selectively induced atrial interstitial fibrosis, contributing to $\mathrm{AF}$ vulnerability [16,17]. Inhibition of TGF $\beta 1$ expression by certain drug decreased the atrial fibrosis and AF vulnerability[18]. These studies suggest that TGF $\beta 1$ play an essential role in inducing AF.

The expression of TGF $\beta 1$ is under gene control. Several functional polymorphisms in the TGF $\beta 1$ gene had been determined previously. Some of these functional polymorphisms, e.g. $(+869 \mathrm{~T} \rightarrow \mathrm{C}$ at codon 10 and $+915 \mathrm{G} \rightarrow \mathrm{C}$ at codon 25) are reported to be associated with cardiovascular disorders, including myocardial infarction, artery stiffness and LVH in hypertensives [19-25].

To date, the association between TGF $\beta 1$ gene polymorphism and the occurrence of AF in hypertensive subjects remains unknown. We hypothesized that the TGF $\beta 1$ polymorphisms genetically determined the 
predisposition to AF in hypertensives. In current study, we recruited newly diagnosed essential hypertensives with and without AF to testify this hypothesis.

\section{Methods}

\section{Subject Enrollment}

Newly diagnosed essential hypertensive subjects were enrolled in this study. The subjects with documented $\mathrm{AF}$ were assigned into the $\mathrm{EH}+\mathrm{AF}+$ group and those with sinus rhythm were assigned into the EH+AFgroup. To avoid any possible influence of certain antihypertensive drugs on the onset of AF, all subjects received no treatment when they were enrolled. Hypertension was defined as systolic blood pressure $(\mathrm{SBP})>=$ $140 \mathrm{~mm} \mathrm{Hg}$, or diastolic blood pressure $(\mathrm{DBP})>=$ $90 \mathrm{~mm} \mathrm{Hg}$ in supine position, after $20 \mathrm{~min}$ of rest on 2 separate days. AF was determined by 12 -lead electrocardiography (ECG) and/or 24-h Holter monitoring. Prior or current documented permanent or paroxysmal AF was considered as AF subjects. Clinical characteristics such as age, sex, body mass index (BMI), and smoking status were collected. Patients with secondary hypertension, coronary heart disease, diabetes myocardial infarction and/or other significant heart problems, such as severe valvular heart disease, dilated phase HCM, congenital heart disease, having other types of arrhythmia, was excluded. Informed consent was obtained from each subject and the Institutional Ethninc Board of the university approved the study.

\section{Plasma measurements}

Blood was collected at morning from resting and fasting subjects. Lipid profiles (total cholesterol, TC and triglycerides, TG) were determined by enzymatic-colorimetric methods according to manufacturer instructions on a Beckman spectrophotometer (Beckman, USA). LDL-C was calculated by the Friedewald's formula. The serum $C$ reaction protein (CRP) concentration was measured by high sensitivity enzyme immunoassay (Dade-Behring, Marburg Germany) for the quantitative determination.

\section{Serum TGF $\beta 1$ detection}

The serum TGF $\beta 1$ was measured using the BDA19 capture ELISA as described previously[26]. The intraassay coefficient of variation of the assay used is $6.8 \%$ and the sensitivity (defined as $2 \mathrm{SD}$ above the mean of 16 blank determinations) was $\sim 0.1 \mathrm{ng} / \mathrm{ml}$.

\section{Genotyping}

DNA was isolated from the whole blood according to standard procedures. Genotyping of the TGF-1 polymorphisms of the $+869 \mathrm{~T} \rightarrow \mathrm{C}$ at codon 10 and $+915 \mathrm{G}$ $\rightarrow \mathrm{C}$ at codon 25 was performed. Briefly, $20 \mu \mathrm{L}$ of genomic DNA solution was added to D-mix, which contains the dNTPs and reaction buffer, for the cytokine genotyping. Taq polymerase (1.1 $\mu \mathrm{L}$; Gibco BRL, USA) was then added to the D-mix, vortexed for 15 seconds, and $10 \mu \mathrm{L}$ of the D-mix mixture transferred to a 96-well microtiter genotyping tray with dried primers in each reaction well. A Perkin-Elmer 9600 thermocycler was used to amplify the promoter regions by PCR. Samples were subjected to 10 cycles at $96^{\circ} \mathrm{C}$ for 10 seconds, and $63^{\circ} \mathrm{C}$ for 60 seconds, followed by 20 cycles at $96^{\circ} \mathrm{C}$ for 10 seconds, annealing temperature of $59^{\circ} \mathrm{C}$ for $50 \mathrm{sec}-$ onds, and $72^{\circ} \mathrm{C}$ for 30 seconds. After the PCR process, the amplified DNA fragments were separated by agarose gel electrophoresis and visualized by staining with ethidium bromide and exposure to ultraviolet light in an UV transilluminator.

\section{Statistical analysis}

All data were analyzed by SPSS (version 13.0) software. The clinical characterstics between $\mathrm{EH}+\mathrm{AF}+$ and $\mathrm{EH}+\mathrm{AF}$ - were compared by $t$ test. The Serum TGF $\beta 1$ levels according to the genotype distributions were performed by the ANOVA test and pos hoc analysis. The genotype distributions and allele frequencies of TGF $\beta 1$ in two groups were evaluated by $\chi^{2}$-test. Logistic regression analysis was performed to assess the odd ratio (OR) for AF in $\mathrm{EH}$ subjects. $\mathrm{P}$ value $\leq 0.05$ was considered statistically significant.

\section{Results}

The clinical and biochemical data of all subjects were listed in Table 1. There were no significant differences in age, sex, height, weight, BMI, SBP, DBP, serum TG, TC, HDL-C, and LDL-C between EH+AF- and EH+AFgroups. The mean serum CRP level was markedly higher in the $\mathrm{EH}+\mathrm{AF}+$ group than in the $\mathrm{EH}+\mathrm{AF}$ - group.

\section{Table 1 Clinical and biochemical characteristics of} all subjects

\begin{tabular}{cccc}
\hline & AF+ & AF- & P \\
\hline Age $($ years $)$ & $45.6 \pm 6.7$ & $46.1 \pm 4.9$ & NS \\
\hline Height $(\mathrm{cm})$ & $175.4 \pm 8.5$ & $175.2 \pm 6.4$ & NS \\
\hline Weight $(\mathrm{kg})$ & $58.6 \pm 9.2$ & $59.1 \pm 5.8$ & $\mathrm{NS}$ \\
\hline Smoker $(\%)$ & 66.4 & 47.8 & 0.02 \\
\hline $\mathrm{SBP}(\mathrm{mmHg})$ & $155.6 \pm 11.4$ & $153.9 \pm 9.9$ & $\mathrm{NS}$ \\
\hline $\mathrm{DBP}(\mathrm{mmHg})$ & $89.6 \pm 6.8$ & $90.6 \pm 7.5$ & $\mathrm{NS}$ \\
\hline $\mathrm{BMl}$ & $25.6 \pm 1.6$ & $25.9 \pm 2.1$ & $\mathrm{NS}$ \\
\hline $\mathrm{TG}(\mathrm{mg} / \mathrm{dl})$ & $122 \pm 13.7$ & $124 \pm 9.6$ & $\mathrm{NS}$ \\
\hline $\mathrm{TC}(\mathrm{mg} / \mathrm{dl})$ & $196.6 \pm 14.8$ & $200.5 \pm 16.3$ & $\mathrm{NS}$ \\
\hline $\mathrm{HDL}-\mathrm{C}(\mathrm{mg} / \mathrm{dl})$ & $49.8 \pm 5.8$ & $51.5 \pm 8.2$ & $\mathrm{NS}$ \\
\hline $\mathrm{LDL}-\mathrm{C}(\mathrm{mg} / \mathrm{dl})$ & $113.7 \pm 10.8$ & $111.6 \pm 8.1$ & $\mathrm{NS}$ \\
\hline $\mathrm{CRP}(\mathrm{mg} / \mathrm{dl})$ & $2.116 \pm 0.08$ & $1.081 \pm 0.06$ & $<0.001$ \\
\hline $\mathrm{TGF} \beta 1(\mathrm{ng} / \mathrm{ml})$ & $2.23 \pm 0.12$ & $2.22 \pm 0.16$ & $\mathrm{NS}$ \\
\hline
\end{tabular}


Smokers were more prevalent in $\mathrm{EH}+\mathrm{AF}+$ group than in $\mathrm{EH}+\mathrm{AF}$ - group. The mean serum TGF $\beta 1$ levels did not show significant difference between two groups.

Table 2. showed the genotype distributions and allele frequencies of TGF $\beta 1$ in two groups. All the allele frequencies fit in with the Hardy-Weinberg equilibrium law. For the polymorphisms of $+915 \mathrm{G} \rightarrow \mathrm{C}$ at codon 25 , the GG genotype was more prevalent in the $\mathrm{EH}+\mathrm{AF}$ + subjects than in the $E H+A F-$ subjects $(P=0.009)$. For the polymorphisms of $+869 \mathrm{~T} \rightarrow \mathrm{C}$ at codon 10 , no significant difference were noted between the two groups $(\mathrm{P}=0.075)$.

Figure 1. showed the serum TGF $\beta 1$ levels according to the genotype profiles. Although Table 1 . showed no significant difference Iin the overall mean TGF $\beta 1$ levels between $\mathrm{EH}+\mathrm{AF}+$ and $\mathrm{EH}+\mathrm{AF}$ - groups $(2.23 \pm 0.12$ vs. $2.22 \pm 0.16$, NS), we observed that the subjects with GG genotype from $\mathrm{EH}+\mathrm{AF}+$ group had the highest mean serum TGF $\beta 1$ level, which was significantly higher than that of GG genotype subjects from EH+AFgroup $(3.18 \pm 0.24$ vs. $2.29 \pm 0.14, \mathrm{ng} / \mathrm{dl}, \mathrm{P}<0.05)$. When it was compared to the $\mathrm{GC}$ and $\mathrm{CC}$ genotypes from both $\mathrm{EH}+\mathrm{AF}+$ and $\mathrm{EH}+\mathrm{AF}$ - groups, statistically

Table 2 Distributions of genotype distribution and allele frequenies of TGF $\beta 1$

\begin{tabular}{lcccc}
\hline & EH+Af+ $(\mathbf{n}=\mathbf{2 4 0})$ & $\mathbf{E H}+\mathbf{A f}-(\mathbf{n}=\mathbf{3 0 0})$ & $\mathbf{X}^{\mathbf{2}}$ & $\mathbf{P}$ \\
\hline Condon $25 \mathrm{G} / \mathrm{C}$ & & & & \\
\hline $\mathrm{GG}$ & 106 & 94 & 9.54 & 0.009 \\
\hline $\mathrm{GC}$ & 74 & 110 & & \\
\hline $\mathrm{CC}$ & 60 & 96 & & \\
\hline Condon $10 \mathrm{~T} / \mathrm{C}$ & & & & \\
\hline $\mathrm{TT}$ & 87 & 108 & 0.52 & 0.975 \\
\hline $\mathrm{TC}$ & 79 & 97 & & \\
\hline $\mathrm{CC}$ & 74 & 95 & & \\
\hline
\end{tabular}

differences were noted as well (all $\mathrm{P}<0.05$ ). For the genotypes from the $+869 \mathrm{~T} \rightarrow \mathrm{C}$ at codon 10 , the mean TGF $\beta 1$ levels were similar among subjects with different genotypes in both $\mathrm{EH}+\mathrm{AF}+$ and $\mathrm{EH}+\mathrm{AF}$ - groups.

Table 3. showed the odd ratio (OR) for AF in EH subjects. As determined by the logistic regression analysis, the TGF $\beta 1$ GG genotype presented a 3.09 times higher risk in developing AF in the multivariate model after adjusting for age and gender. As shown in Table 3., the other risk factors for AF subjects included age, CRP level and smoke.

\section{Discussion}

The present study assessed the association between the single nucleotide polymorphisms at the TGF $\beta 1$ locus and AF in subjects with essential hypertension. We found that the GG genotype of TGF $\beta 1+915 \mathrm{G}->\mathrm{C}$ at codon 25 was more prevalent in the individuals with $\mathrm{AF}$ than those without. Multiple analyses revealed that the GG genotype carriers presented an odd ratio of 3.09 for developing AF. The $+869 \mathrm{~T}->\mathrm{C}$ at codon 10 showed no positive relation with AF. As far as we know, this is the first study regarding the association between the TGF $\beta 1$ polymorphisms and AF in hypertensives.

TGF $\beta 1$ is a cytokine that regulates the synthesis of extracellular matrix components such as collagen, fibronectin, and proteoglycan. The role of TGF $\beta 1$ in cardiac fibrosis and AF had been studied. Over-expression of

Table 3 OR to AF determined by logistic regressiona analysis

\begin{tabular}{lcc}
\hline \multicolumn{1}{c}{ Variable } & Odd Ratio $\mathbf{( 9 5 \% ~ C l )}$ & $\mathbf{P}$ \\
\hline TGF $\beta$ 1 GG genotype & $3.09(2.11-6.59)$ & $<0.01$ \\
\hline Age (years) & $1.45(1.11-2.32)$ & 0.04 \\
\hline CRP $(\mathrm{mg} / \mathrm{dl})$ & $1.81(1.15-3.49)$ & 0.03 \\
\hline Smoker $(\%)$ & $2.47(1.98-4.66)$ & 0.01 \\
\hline
\end{tabular}

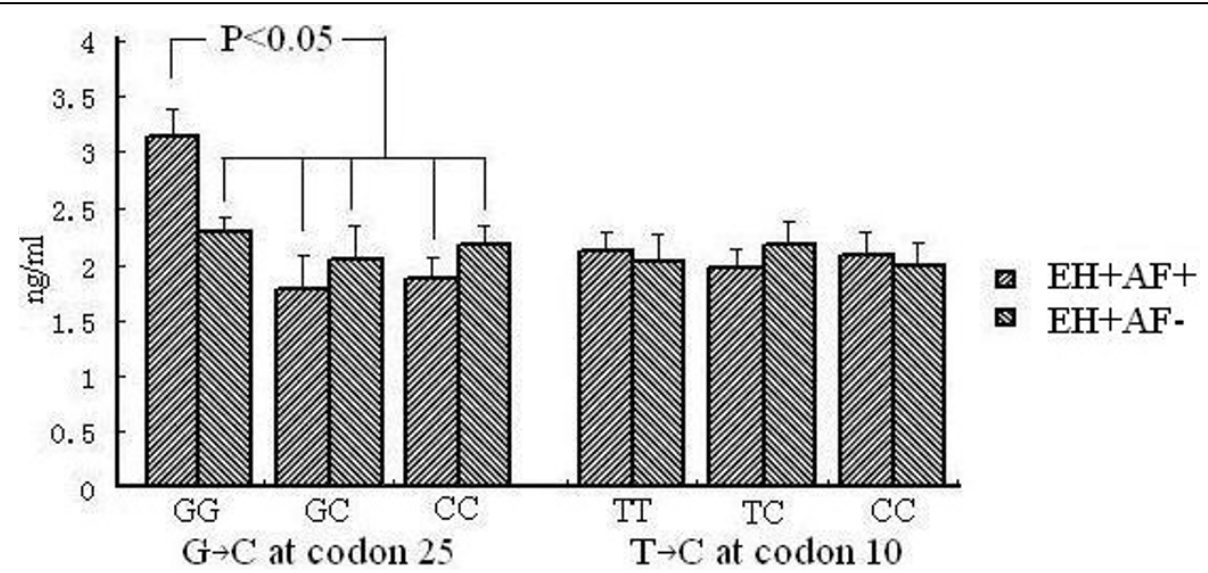

Figure 1 Serum TGF $\beta 1$ level according to the genotype profile. 
TGF $\beta 1$ selectively induced atrial fibrosis, leading to increased conduction heterogeneity and AF vulnerability without affecting the cellular electrophysiology[16]. Inhibition of TGF $\beta 1$ expression by pirfenidone (PFD) significantly reduced the atrial fibrosis, as a result, reduced conduction abnormalities and AF vulnerability were observed[18]. These studies suggest that the TGF $\beta 1$ attribute to development of AF via triggering atrial fibrosis. Higher levels of serum or plasma TGF $\beta 1$ have been observed in subjects with hypertension, in association with cardiac and renal complications [27-31]. The TGF $\beta 1$ condon 25 polymorphisms are located in the signal peptide sequence, which regulate the export of synthesized TGF $\beta 1$ protein across membranes of the endoplasmic reticulum and the activation of protein. Previous studies showed that the TGF $\beta 1$ levels of subjects with GG genotype were markedly higher than those with GC and CC genotypes in heart and lung transplant patients[32,33]. In consistent with these studies, we found that the subjects with codon $25 \mathrm{G} / \mathrm{G}$ genotype had higher TGF $\beta 1$ plasma level in subjects from $\mathrm{EH}+\mathrm{AF}+$ groups than those with the same genotype from $\mathrm{EH}+\mathrm{AF}$ - groups, although no significant difference of overall mean TGF $\beta 1$ levels between $\mathrm{EH}+\mathrm{AF}+$ and $\mathrm{EH}+\mathrm{AF}$ - groups was observed.

In the ECTIM Study, Rao et al. reported the G/C genotype at codon 25 provided a 2.3 -fold greater risk for the presence of vascular disease in hemodialysis patients [22]. Xu and his colleagues reported genetic role of TGF $\beta 1$ Arg25Pro polymorphisms (GC genotype in present study) in the occurrence of left ventricle hypertrophy in EH subjects [25]. Our data showed that the GG genotype, rather than GC genotype, was related to AF incidence in $E H$ subjects. This inconsistency may be explained in part by the difference in study protocol and relatively small scale samples in these studies.

All EH subjects in our study were newly diagnosed and none of them received anti-hypertensive treatment at enrollment. This is important because some antihypertensive agents, e.g. $\beta$ blockers and angiotension converting enzyme inhibitors and Angiotensin II receptor blockers may inhibit the onset and maintenance of AF.

Taken together, in present study we found the GG genotype of TGF $\beta 1+915 \mathrm{G}->\mathrm{C}$ at codon 25 was associated with occurrence of AF in EH subjects. This finding may help to evaluate the risk of developing AF in $\mathrm{EH}$ patients for a reinforced prevention.

\section{Acknowledgements}

We thank Dr.Haifeng Xu for his help in Statistical Analyses.

\section{Author details}

'Department of Interventional Radiology, The Second Hospital of Shandong University, Shangdong, PR China. ${ }^{2}$ Department of Cardiology, The First People Hospital of Hangzhou, Hangzhou, PR China.

\section{Authors' contributions}

$\mathrm{YL}$ participated in the design of the study. YW, XW and ZL conducted the serum TGF $\beta 1$ detection and genotyping, YW wrote the manuscript. $\mathrm{XH}$ and XS performed the statistical analysis. All authors read and approved the final manuscript.

\section{Competing interests}

The authors declare that they have no competing interests.

Received: 28 January 2010 Accepted: 31 March 2010

Published: 31 March 2010

\section{References}

1. Zhou Z, Hu D: An epidemiological study on the prevalence of atrial fibrillation in the Chinese population of mainland China. J Epidemiol 2008, 18:209-216.

2. Stewart S, Murphy NF, Walker A, McGuire A, McMurray JJ: Cost of an emerging epidemic: an economic analysis of atrial fibrillation in the UK. Heart 2004, 90:286-292

3. Lloyd-Jones DM, Wang TJ, Leip EP, Larson MG, Levy D, Vasan RS, D'Agostino RB, Massaro JM, Beiser A, Wolf PA, Benjamin EJ: Lifetime risk for development of atrial fibrillation: the Framingham Heart Study. Circulation 2004, 110:1042-1046.

4. Minami M, Kobayashi $Y$, Toyokawa S, Inoue K, Takeshita Y: Risk factors for new-onset atrial fibrillation during routine medical checkups of Japanese male workers. Int Heart J 2009, 50:457-464.

5. Vester EG: [Arterial hypertension and cardiac arrhythmias]. Dtsch Med Wochenschr 2008, 133(Suppl 8):S261-265.

6. Go O, Rosendorff C: Hypertension and atrial fibrillation. Curr Cardiol Rep 2009, 11:430-435.

7. Grammer JB, Bohm J, Dufour A, Benz M, Lange R, Bauernschmitt R: Atrial fibrosis in heart surgery patients Decreased collagen III/I ratio in postoperative atrial fibrillation. Basic Res Cardiol 2005, 100:288-294.

8. Boldt A, Wetzel U, Lauschke J, Weigl J, Gummert J, Hindricks G, Kottkamp H, Dhein S: Fibrosis in left atrial tissue of patients with atrial fibrillation with and without underlying mitral valve disease. Heart 2004, 90:400-405

9. Burstein B, Nattel S: Atrial fibrosis: mechanisms and clinical relevance in atrial fibrillation. J Am Coll Cardiol 2008, 51:802-809.

10. Everett THt, Olgin JE: Atrial fibrosis and the mechanisms of atrial fibrillation. Heart Rhythm 2007, 4:S24-27.

11. Frustaci A, Chimenti C, Bellocci F, Morgante E, Russo MA, Maseri A: Histological substrate of atrial biopsies in patients with lone atrial fibrillation. Circulation 1997, 96:1180-1184

12. Goette A: Nicotine, atrial fibrosis, and atrial fibrillation: do microRNAs help to clear the smoke? Cardiovasc Res 2009, 83:421-422.

13. Luo MH, Li YS, Yang KP: Fibrosis of collagen I and remodeling of connexin 43 in atrial myocardium of patients with atrial fibrillation. Cardiology 2007, 107:248-253.

14. Pellman J, Lyon RC, Sheikh F: Extracellular matrix remodeling in atrial fibrosis: Mechanisms and implications in atrial fibrillation. $J \mathrm{Mol}$ Cell Cardiol 2009

15. Spach MS: Mounting evidence that fibrosis generates a major mechanism for atrial fibrillation. Circ Res 2007, 101:743-745.

16. Verheule $S$, Sato T, Everett T, Engle SK, Otten D, Lohe Rubart-von der M, Nakajima HO, Nakajima H, Field LJ, Olgin JE: Increased vulnerability to atrial fibrillation in transgenic mice with selective atrial fibrosis caused by overexpression of TGF-beta1. Circ Res 2004, 94:1458-1465.

17. Gramley F, Lorenzen J, Koellensperger E, Kettering K, Weiss C, Munzel T: Atrial fibrosis and atrial fibrillation: The role of the TGF-beta(1) signaling pathway. Int J Cardiol 2009

18. Bunch TJ, Mahapatra S, Bruce GK, Johnson SB, Miller DV, Horne BD, Wang $X \mathrm{~L}$, Lee $\mathrm{HC}$, Caplice NM, Packer DL: Impact of transforming growth factor-beta 1 on atrioventricular node conduction modification by injected autologous fibroblasts in the canine heart. Circulation 2006 113:2485-2494

19. Cambien F, Ricard S, Troesch A, Mallet C, Générénaz L, Evans A, Arveiler D, LuC G, Ruidavets JB, Poirier O: Polymorphisms of the transforming growth factor-beta 1 gene in relation to myocardial infarction and blood pressure. The Etude Cas-Temoin de I'Infarctus du Myocarde (ECTIM) Study. Hypertension 1996, 28:881-887. 
20. Crobu F, Palumbo L, Franco E, Bergerone S, Carturan S, Guarrera S, Frea S, Trevi G, Piazza A, Matullo G: Role of TGF-beta1 haplotypes in the occurrence of myocardial infarction in young Italian patients. BMC medical genetics 2008, 9:13.

21. Koch W, Hoppmann P, Mueller JC, Schomig A, Kastrati A: Association of transforming growth factor-beta1 gene polymorphisms with myocardial infarction in patients with angiographically proven coronary heart disease. Arteriosclerosis, thrombosis, and vascular biology 2006, 26:1114-1119.

22. Rao M, Guo D, Jaber BL, Tighiouart H, Pereira BJ, Balakrishnan VS: Transforming growth factor-beta 1 gene polymorphisms and cardiovascular disease in hemodialysis patients. Kidney international 2004, 66:419-427.

23. Sie MP, Mattace-Raso FU, Uitterlinden AG, Arp PP, Hofman A, Hoeks AP, Reneman RS, Asmar R, van Duijn CM, Witteman JC: TGF-beta1 polymorphisms and arterial stiffness; the Rotterdam Study. Journal of human hypertension 2007, 21:431-437.

24. Syrris P, Carter ND, Metcalfe JC, Kemp PR, Grainger DJ, Kaski JC, Crossman DC, Francis SE, Gunn J, Jeffery S, Heathcote K: Transforming growth factor-beta1 gene polymorphisms and coronary artery disease. Clin Sci (Lond) 1998, 95:659-667.

25. Xu HY, Hou XW, Wang LF, Wang NF, XU J: Association between transforming growth factor beta1 polymorphisms and left ventricle hypertrophy in essential hypertensive subjects. Molecular and cellular biochemistry 2009, 335:13-17.

26. Grainger DJ, Heathcote K, Chiano M, Snieder H, Kemp PR, Metcalfe JC, Carter ND, Spector TD: Genetic control of the circulating concentration of transforming growth factor type beta1. Human molecular genetics 1999, 8:93-97.

27. Peterson MC: Circulating transforming growth factor beta-1: a partial molecular explanation for associations between hypertension, diabetes, obesity, smoking and human disease involving fibrosis. Med Sci Monit 2005, 11:RA229-232.

28. Laviades C, Varo N, Diez J: Transforming growth factor beta in hypertensives with cardiorenal damage. Hypertension 2000, 36:517-522

29. Sanderson JE, Lai KB, Shum IO, Wei S, Chow LT: Transforming growth factor-beta(1) expression in dilated cardiomyopathy. Heart (British Cardiac Society) 2001, 86:701-708.

30. Mahmoudabady M, Mathieu M, Dewachter L, Hadad I, Ray L, Jespers P, Brimioulle S, Naeije R, McEntee K: ctivin-A, transforming growth factorbeta, and myostatin signaling pathway in experimental dilated cardiomyopathy. Journal of cardiac failure 2008, 14:703-709.

31. Derhaschnig U, Shehata M, Herkner H, Bur A, Woisetschläger C, Laggner AN, Hirschl MM: Increased levels of transforming growth factorbeta1 in essential hypertension. American journal of hypertension 2002, 15:207-211.

32. Aziz TM, Burgess M, Hasleton PS, Yonan N, Deiraniya AK, Hutchinson IV: Transforming growth factor-beta: association with arteriosclerosis and left ventricular dysfunction after heart transplantation. Transplantation proceedings 2001, 33:2334-2336.

33. Awad MR, El-Gamel A, Hasleton P, Turner DM, Sinnott PJ, Hutchinson IV: Genotypic variation in the transforming growth factor-beta1 gene: association with transforming growth factor-beta1 production, fibrotic lung disease, and graft fibrosis after lung transplantation. Transplantation 1998, 66:1014-1020.

doi:10.1186/1423-0127-17-23

Cite this article as: Wang et al:: Association between transforming growth factor $\beta 1$ polymorphisms and atrial fibrillation in essential hypertensive subjects. Journal of Biomedical Science 2010 17:23.

\section{Submit your next manuscript to BioMed Central and take full advantage of:}

- Convenient online submission

- Thorough peer review

- No space constraints or color figure charges

- Immediate publication on acceptance

- Inclusion in PubMed, CAS, Scopus and Google Scholar

- Research which is freely available for redistribution

Submit your manuscript at www.biomedcentral.com/submit
C Biomed Central 